\title{
QUALITY OF CAGAITA POWDER BY FOAM LAYER DRYING METHOD AND DIFFERENT FOAMER AGENTS
}

\author{
Maisa D. Cavalcante ${ }^{1}$, Celso M. Belisário ${ }^{1 *}$, Daniel Emanuel C. de Oliveira², \\ Geisa Priscilla A. G. Maia ${ }^{1}$
}

${ }^{*}$ Corresponding author. Instituto Federal Goiano - Campus Rio Verde/ Rio Verde - GO, Brasil.

E-mail: celso.belisario@ifgoiano.edu.br | ORCID ID: https://orcid.org/0000-0001-8693-6384

\section{KEYWORDS}

Cerrado fruits, cagaita powder, bioactive compounds, antioxidant activity, vitamin $\mathrm{C}$, vitamin $\mathrm{A}$, carotenoids, foam layer drying.

\begin{abstract}
One of the factors that hinder the usability of Cerrado fruits is their perishable nature, requiring industrial processing to ensure prolonged shelf life. This study aims to determine the optimal foaming agent for industrial processing of this fruit, and to evaluate the physicochemical characteristics and antioxidant activity of dried cagaita powder (Eugenia dysenterica DC) in foam layers at temperatures of $40,50,60$, and $70{ }^{\circ} \mathrm{C}$. The effectiveness of three foaming agents at various concentrations were tested, and suitable agents were identified based on a factorial analysis of density, expansion, and stability. The physicochemical characteristics of the powder, along with its vitamin $\mathrm{A}$ and $\mathrm{C}$ and total carotenoid content and antioxidant activity, were evaluated. Vitamin C levels and antioxidant activity decreased with increasing temperature, but were retained at levels significant enough to establish cagaita as an important source of this vitamin. Higher carotenoid and vitamin A concentrations were found in the powder prepared by drying at 60 and $70{ }^{\circ} \mathrm{C}$. The foam layer drying process employed for processing cagaita pulp reported here proved suitable for maintaining desired physicochemical and bioactive qualities in the final powdered product.
\end{abstract}

\section{INTRODUCTION}

Eugenia dysenterica DC, commonly known as cagaita or cagaiteira, is a native fruit tree of the Brazilian Cerrado, belonging to the Myrtaceae family, which includes approximately 130 genera and 5670 species (Mazuti Silva et al., 2015).

These fruits are unique among many native species due to their varied nutritional composition. Here, we highlight the major components with bioactive properties that have specific metabolic or physiological actions. These include the presence of important micronutrients such as vitamins $\mathrm{C}$ and $\mathrm{A}$, as well as antioxidant activity (Morais et al., 2017).

Previous studies such as Macedo et al. (2017) have reported a relationship between reduction of oxidative stress in organisms, protection against certain types of cardiovascular diseases, and enhanced immunity. Because these substances are not synthesized in the human body, there is a need to consume food rich in the former to ensure their metabolic availability (Palmero et al., 2014).

Various Cerrado fruits are known to contain a high amount of bioactive compounds, along with high antioxidant activity (Moreira-Araújo et al., 2019). However, these fruits are quite perishable, and the bioactive compounds are prone to easy degradation. To avoid such losses and add value to these products, postharvest conservation methods that prolong their shelf life and maintain the high levels of bioactive compounds are necessary (Morais et al., 2017; Araújo et al., 2017).

One of the most widely used techniques for postharvest processing is the foam-layer drying method, where food is converted into stable foam by the addition of foaming agents and aeration (Karim \& Wai, 1999). Drying in an oven leads to the yield of the final product in a powder form, which is highly desirable due to their high solubility in water, high mass/volume ratio, and numerous possibilities for combination with other food products (Moreira et al., 2013).

\footnotetext{
${ }^{1}$ Instituto Federal Goiano - Campus Rio Verde/ Rio Verde - GO, Brasil.

${ }^{2}$ Instituto Federal Goiano - Campus Iporá/ Iporá - GO, Brasil.

Area Editor: Gizele Ingrid Gadotti

Received in: 12-18-2019

Accepted in: 3-19-2020
} 
This study aimed to identify the optimal foaming agent and its lowest concentration that resulted in the formation of a stable foam. We then evaluated the acidity, $\mathrm{pH}$, concentrations of vitamins $\mathrm{A}$ and $\mathrm{C}$ and total carotenoids, and the antioxidant activity of the dried cagaita powder obtained in foam layers at temperatures of $40,50,60$, and $70{ }^{\circ} \mathrm{C}$, with the overall objective of establishing processing conditions that yield a product with superior physicochemical characteristics and bioactivity.

\section{MATERIAL AND METHODS}

\section{Harvest and preparation of pulp}

Cagaita fruits were collected in Montes Claros, Goiás, Brazil $\left(16^{\circ} 06^{\prime} 20^{\prime \prime S}\right.$ and $\left.51^{\circ} 17^{\prime} 11^{\prime \prime} \mathrm{W}\right)$. These were packed in $30 \mathrm{~cm} \times 40 \mathrm{~cm}$ polyethylene bags and placed in thermal boxes, then transported to the IF Goiano - Campus Rio Verde Phytochemical Laboratory, where the fruits were checked for the absence of mechanical injuries and visually uniform maturation stage. These were sanitized in water containing $150 \mathrm{mg} / \mathrm{kg}$ chlorine for $15 \mathrm{~min}$ and dried on paper towels.

The fruits were converted to pulp using a Toturgan ${ }^{\circledR}$ electric pulping machine, which was then packed in $25 \mathrm{~cm} \times 35 \mathrm{~cm}$ polyethylene bags and stored in a freezer at $-18^{\circ} \mathrm{C}$.

\section{Choice of the best foaming formulation}

Three commercially available foaming agents (Emustab ${ }^{\circledR}$, Neutral-Super-Binder ${ }^{\circledR}$ and Albumin) were added to $300 \mathrm{~mL}$ of pulp samples, in proportions of $2,4,6$, 8 and $10 \%(\mathrm{w} / \mathrm{v})$. The resulting mixtures were stirred in an electric mixer for $20 \mathrm{~min}$, and the generated foam was tested for density, expansion, and stability. Pulp and foam densities were measured using a previously calibrated 5 $\mathrm{mL}$ pycnometer and the expansion percentages were calculated from the measured density data according to eqs (1) and (2):

$$
\begin{aligned}
& \rho_{\text {sample }}=\frac{\mathrm{w}_{\text {sample }}}{v_{\text {pycnometer }}} \\
& \operatorname{Exp}=\frac{1 / \rho_{\text {foam }}-1 / \rho_{\text {pulp }}}{1 / \rho_{\text {pulp }}} * 100
\end{aligned}
$$

Where:

$$
\begin{aligned}
& \rho_{\text {sample }} \text { - sample density }\left(\mathrm{g} \mathrm{cm}^{-3}\right) \text {; } \\
& \mathrm{W}_{\text {sample }} \text { - sample weight }(\mathrm{g}) \text {; } \\
& \mathrm{v}_{\text {pycnometer }} \text { - pycnometer volume }\left(\mathrm{cm}^{3}\right) \text {; } \\
& \text { Exp - foam expansion (\%); } \\
& \rho_{\text {foam }} \text { - foam density }\left(\mathrm{g} \mathrm{cm}^{-3}\right) \text {, and } \\
& \rho_{\text {pulp }} \text { - pulp density }\left(\mathrm{g} \mathrm{cm}^{-3}\right) \text {. }
\end{aligned}
$$

Foam stability was evaluated according to the technique described by Karim \& Wai (1999), and calculated from [eq. (3)]:

$$
\text { Stability }(\%)=\frac{1}{\mathrm{~V}_{\text {drained }}}
$$

Where:

$$
\mathrm{V}_{\text {drained }} \text { - volume drained for } 5 \mathrm{~min}(\mathrm{~mL}) \text {. }
$$

In order to choose the most optimal formulation, a completely randomized experimental design was carried out in subdivided plots, with three plots (foaming agents) and five subplots (concentrations). The experiments were performed in triplicates and the results were analyzed using analysis of variance (ANOVA) and means obtained were subjected to the least significant difference (LSD) test $(p<0.05)$. The formulation associated with lowest density, highest stability, and greatest expansion was chosen as the most suitable.

\section{Preparation of cagaita powder and estimation of moisture content}

The best formulation, as identified by methods outlined in the previous section, was used to prepare the cagaita powder under different temperatures of drying. The resultant samples were used for physicochemical and biological evaluations.

The initial moisture content of the product (\% w.b.) was determined be heating $5 \mathrm{~g}$ of the chosen formulation to $105{ }^{\circ} \mathrm{C}$ in a forced air oven for $24 \mathrm{~h}$. The moisture content was then calculated from the ratio of the final and initial mass of the material. The water content of the final product was taken to be the equilibrium water content of the dried samples.

Approximately $100 \mathrm{~g}$ of cagaita foams were arranged in rectangular aluminum trays $(30 \mathrm{~cm} \mathrm{x} 15 \mathrm{~cm} \mathrm{x}$ $2 \mathrm{~cm}$ ) without perforations, resulting in a layer of approximately $1 \mathrm{~cm}$ thickness. The foams were then dried with fan-assisted circulation of hot air in a forced air oven at temperatures of $40,50,60$, and $70^{\circ} \mathrm{C}$. The samples were weighed every $10 \mathrm{~min}$ in the first hour of drying, every 20 min in the second hour, every $30 \mathrm{~min}$ in the third and fourth hours, and every $60 \mathrm{~min}$ beyond the fourth hour. The measurement was terminated mass measurements showed similar values for three consecutive measurements.

After drying, the samples were removed from trays and vacuum packed in plastic containers, then stored in a conventional refrigerator until physicochemical evaluations were performed.

\section{Physicochemical evaluations}

The determination of $\mathrm{pH}$, total titratable acidity, and vitamin $\mathrm{C}$ content was carried out according to procedures described by the Adolf Lutz Institute (IAL, 2008).

\section{Determination of total titratable acidity}

For the determination of titratable acidity, about $5 \mathrm{~g}$ of the cagaita powder was macerated, transferred to a 100 $\mathrm{mL}$ flask, and diluted with distilled water. The titrant solution was $0.1 \mathrm{M}$ sodium hydroxide, and the indicator was $1 \%(\mathrm{~m} / \mathrm{v})$ phenolphthalein in an ethanolic solution.

\section{Estimation of vitamin $\mathbf{C}$ content}

About $10 \mathrm{~g}$ of the cagaita powder was weighed and transferred to a $300 \mathrm{~mL}$ Erlenmeyer flask with $50 \mathrm{~mL}$ of water. Then, $10 \mathrm{~mL}$ of a $20 \%$ sulfuric acid solution was added. After homogenization, $1 \mathrm{~mL}$ of $10 \%(\mathrm{w} / \mathrm{v})$ aqueous potassium iodide solution and $1 \mathrm{~mL}$ of $1 \%(\mathrm{w} / \mathrm{v})$ aqueous starch solution were added. The resulting solution was titrated with $0.002 \mathrm{M}$ potassium iodate solution until blue color was observed. The amount of vitamin $\mathrm{C}$ was calculated using [eq. (4)] (IAL, 2008): 


$$
\operatorname{vitamin} \mathrm{C}(\mathrm{mg} / 100 \mathrm{~g})=(100 * \mathrm{v} * \mathrm{~F}) / \mathrm{p}
$$

Where:

$$
\begin{aligned}
& \mathrm{v} \text { - volume of iodate consumed; } \\
& \mathrm{F}-8.806 \text { or } 0.8806 \text { for } 0.02 \mathrm{M} \text { or } 0.002 \mathrm{M} \mathrm{KIO}_{3} \text {, } \\
& \text { respectively, and } \\
& \text { p - sample mass }(\mathrm{g}) \text {. }
\end{aligned}
$$

\section{Evaluation of antioxidant capacity}

Antioxidant activity was determined by the $\beta$ carotene/linoleic acid method, according to Rufino et al. (2006).

For this, $500 \mathrm{~mL}$ of distilled water was bubbled with oxygen for $30 \mathrm{~min}$. Aqueous solutions of $70 \%(\mathrm{v} / \mathrm{v})$ methanol and 50\% (v/v) acetone were prepared. A $\beta$ carotene/linoleic acid emulsion was prepared in a $500 \mathrm{~mL}$ Erlenmeyer flask by mixing $40 \mu \mathrm{L}$ linoleic acid, $530 \mu \mathrm{L}$ Tween $40,50 \mu \mathrm{L} \beta$-carotene solution, and $1 \mathrm{~mL}$ chloroform.

Then, chloroform was evaporated with the help of an oxygenator, and portions of the water bubbled with oxygen were added to the emulsion until the UV/Vis absorbance at $470 \eta \mathrm{m}$ was between 0.6 and 0.7 , as determined using distilled water as a blank. The positive control was the synthetic antioxidant Trolox ${ }^{\circledR}$ (6-hydroxy2,5,7,8-tetramethylchroman-2-carboxylic acid). For analysis, a $10 \mathrm{~mL}$ ethanolic solution of this reagent at a 20 $\mathrm{mg} \mathrm{L}^{-1}$ concentration was freshly prepared before use.

To obtain the extracts, about $3 \mathrm{~g}$ of the cagaita powder from each treatment was weighed in triplicate, 40 $\mathrm{mL}$ of methanol was added, and the system was left at rest for $1 \mathrm{~h}$. The supernatant was removed and transferred to a $100 \mathrm{~mL}$ balloon, and $40 \mathrm{~mL}$ of acetone solution was added to the solid material, while maintaining the same time for methanol extraction. The supernatant was added to the flask containing the methanolic fraction, and the final volume was made up with distilled water.

The reaction mixtures for the estimation of the antioxidant capacity were prepared in $10 \mathrm{~mL}$ flasks each, by adding $0.4 \mathrm{~mL}$ of the extract and $5 \mathrm{~mL}$ of $\beta$ carotene/linoleic acid solution. As the positive control, a mixture of $0.4 \mathrm{~mL}$ of Trolox solution and $5 \mathrm{~mL}$ of $\beta$ carotene/linoleic acid solution was used. The negative control was a mixture of $5 \mathrm{~mL}$ of the test solution and 0.4 $\mathrm{mL}$ of distilled water. The reduction in absorbance was assumed to be $100 \%$ in the absence of the antioxidant. Readings were performed at $450 \eta \mathrm{m}$ using distilled water as the blank. The initial reading was carried out after 2 min of mixing, followed by another at the end of $2 \mathrm{~h}$.

From [eq. (5)], the antioxidant capacity (\%) of the extracts and the positive control were calculated:

$\mathrm{I}(\%)=100-[(\operatorname{Red}$ abs sample $) * 100) /(\operatorname{Red}$ abs system $)]$

Where:

\section{I (\%) - inhibition of system oxidation;}

Red abs sample - difference between initial and final absorbance values of the sample or positive control, and

Red abs system - difference between initial and final absorbance values of the negative control.

\section{Determination of total carotenoid content}

For determination of the carotenoid $\left(\mu \mathrm{g} \mathrm{g} \mathrm{g}^{-1}\right)$ and vitamin A (retinol activity equivalents (RAE) per $100 \mathrm{~g}$ of sample) content, the methodology described by Souza et al. (2012) was utilized. About $5 \mathrm{~g}$ of the sample from each treatment in triplicates was macerated with about $30 \mathrm{~mL}$ of cold acetone and $5 \mathrm{~g}$ of Hyflo Supercel for $2 \mathrm{~min}$, followed by vacuum filtration. The extraction was repeated six times until the filtrate became as clear as possible.

The filtrate was then transferred to a $250 \mathrm{~mL}$ separation funnel containing $50 \mathrm{~mL}$ of cold petroleum ether. Three consecutive washes were performed with 100 $\mathrm{mL}$ of distilled water to remove acetone. The etherdissolved phase was transferred to an amber flask; then, the same volume of $10 \%(\mathrm{w} / \mathrm{v}) \mathrm{KOH}$ methanolic solution was added, and the mixture was stored at room temperature for $24 \mathrm{~h}$ for saponification of lipids and chlorophyll.

This mixture was then transferred to a separation funnel containing $50 \mathrm{~mL}$ of cold petroleum ether, followed by washing with $50 \mathrm{~mL}$ aliquots of distilled water until the $\mathrm{pH}$ of the ether phase was near neutral. About $3 \mathrm{~g}$ of anhydrous sodium sulfate was added, the mixture was filtered, and the ether extract was concentrated on a rotary evaporator $\left(35^{\circ} \mathrm{C}\right.$ and $\left.90 \mathrm{rpm}\right)$. The concentrate was transferred to a $50 \mathrm{~mL}$ balloon and diluted to the desired volume with petroleum ether.

Total carotenoid quantification was performed using the scanning method with readings from 300 to 700 $\eta \mathrm{m}$ on a UV/Vis spectrometer, using [eq. (6)]:

$$
\mathrm{CT}=\frac{\mathrm{Abs}^{*} \mathrm{Vol}^{*} 10^{4}}{\mathrm{E}_{1}^{1 \%} \mathrm{~cm} * \mathrm{P}}
$$

Where:

CT - total carotenoid $\left(\mu \mathrm{g} \mathrm{g}^{-1}\right)$;

Abs - maximum absorbance;

Vol - dilution volume $(\mathrm{mL})$;

$\mathrm{E}_{1 \mathrm{~cm}}^{1 \%}$ - molar extinction coefficient in petroleum ether ( $\beta$-Carotene: 2592$)$, and

$\mathrm{P}$ - Sample weight $(\mathrm{g})$.

Using the data obtained from the total carotenoids in $\beta$-Carotene, vitamin A was calculated in units of $\mu \mathrm{g}$ RAE per $100 \mathrm{~g}$ of sample (Souza et al., 2012).

The experimental design for the physicochemical analysis was completely randomized in four plots (drying temperatures). Evaluations were performed in triplicates. Results were subjected to ANOVA and the means were compared using an LSD test $(p<0.05)$. Water loss is represented by a trend line in a graph plotting mass versus drying time.

\section{RESULTS AND DISCUSSION}

According to the ANOVA (Table 1), there was a significant difference (to the level of $1 \%$ ) in all the analyzed variables across all types of foaming agents used (Emustab ${ }^{\circledR}$, Neutral-Super-Binder ${ }^{\circledR}$ and commercially available albumin), subplots (concentrations), and their interactions (foaming agent $\mathrm{x}$ concentration). 
TABLE 1. Summary of analysis of variance of cagaita pulp foams made with the addition of three foamer agents at different concentrations. Foam density - $\rho\left(\mathrm{g} \mathrm{cm}^{-3}\right)$, Foam expansion - Exp $(\%)$ and Stability - Stab (\%).

\begin{tabular}{ccccc}
\hline \multirow{2}{*}{ Factors and interactions } & DF & \multicolumn{3}{c}{ Mean squares } \\
\cline { 3 - 5 } & & $\mathbf{P}$ & $\mathbf{E x p}$ & $10101.86^{* *}$ \\
Foamer $(\mathrm{F})$ & 2 & $1.453^{* *}$ & $10.56^{* *}$ & $9725.15^{* *}$ \\
Concentration $(\mathrm{C})$ & 4 & $0.017^{* *}$ & $0.66^{* *}$ & $1940.58^{* *}$ \\
Interaction F*C & 8 & $0.012^{* *}$ & $0.55^{* *}$ & 7.23 \\
CV $(\%)$ & & 4.09 & 13.87 & \\
\hline
\end{tabular}

** Significant in an $\mathrm{F}$ test at the level of $1 \%$.

Table 2 presents the unfolding of the interactions between the different foaming agents and their concentration in the formulation of cagaita pulp foams.

TABLE 2. Unfolding of density, expansion and stability of the cagaita pulp foam produced with different foaming agents and concentrations. Foam density $-\rho\left(\mathrm{g} \mathrm{cm}^{-3}\right)$, Foam expansion - $\operatorname{Exp}(\%)$ and Stability - Stab $(\%)$.

\begin{tabular}{|c|c|c|c|c|c|c|c|c|c|}
\hline \multirow[b]{3}{*}{ C } & \multicolumn{3}{|c|}{$\mathbf{P}$} & \multicolumn{3}{|c|}{$\operatorname{Exp}$} & \multicolumn{3}{|c|}{ Stab } \\
\hline & \multicolumn{9}{|c|}{ Foamer } \\
\hline & Emustab ${ }^{\circledR}$ & $\begin{array}{c}\text { Neutral- } \\
\text { Super- } \\
\text { Binder } \mathbb{R} \\
\end{array}$ & Albumin & Emustab ${ }^{\circledR}$ & $\begin{array}{c}\text { Neutral- } \\
\text { Super- } \\
\text { Binder } \AA \\
\end{array}$ & Albumin & Emustab ${ }^{\circledR}$ & $\begin{array}{c}\text { Neutral- } \\
\text { Super- } \\
\text { Binder } \mathbb{R}\end{array}$ & Albumin \\
\hline 2 & $0.44 \mathrm{cA}$ & $0.98 \mathrm{aA}$ & $0.53 \mathrm{bA}$ & $1.35 \mathrm{aB}$ & $0.045 \mathrm{cA}$ & $0.91 \mathrm{bC}$ & $2.00 \mathrm{bC}$ & $1.057 \mathrm{bC}$ & $6.66 \mathrm{aD}$ \\
\hline 4 & $0.40 \mathrm{cA}$ & $0.93 \mathrm{aA}$ & $0.56 \mathrm{bA}$ & $1.52 \mathrm{aB}$ & $0.104 \mathrm{cA}$ & $0.82 \mathrm{bC}$ & $3.33 \mathrm{cC}$ & $6.66 \mathrm{bB}$ & $50.00 \mathrm{aB}$ \\
\hline 6 & $0.40 \mathrm{cA}$ & $0.98 \mathrm{aA}$ & $0.48 \mathrm{bB}$ & $1.56 \mathrm{aB}$ & $0.047 \mathrm{cA}$ & $1.12 \mathrm{bC}$ & $5.00 \mathrm{bC}$ & $0.909 \mathrm{cC}$ & $38.00 \mathrm{aC}$ \\
\hline 8 & $0.40 \mathrm{bA}$ & $0.95 \mathrm{aA}$ & $0.29 \mathrm{cC}$ & $1.58 \mathrm{bB}$ & $0.078 \mathrm{cA}$ & $2.54 \mathrm{aA}$ & $10.00 \mathrm{bB}$ & $100.0 \mathrm{aA}$ & $100.0 \mathrm{aA}$ \\
\hline 10 & $0.32 \mathrm{bB}$ & $0.96 \mathrm{aA}$ & $0.44 \mathrm{cB}$ & $2.21 \mathrm{aA}$ & $0.075 \mathrm{cA}$ & $1.34 \mathrm{bB}$ & $20.00 \mathrm{bA}$ & $100.0 \mathrm{aA}$ & $100.0 \mathrm{aA}$ \\
\hline
\end{tabular}

C- Foamer concentration (\%). Means followed by different lowercase letters in the same row, and different uppercase letters in the same column, indicate significant difference by the LSD test at $5 \%$ significance.

The foam in the presence of albumin had a lower density and greater expansion in a $8 \%(\mathrm{w} / \mathrm{v})$ concentration, and also showed greater stability in 8 and $10 \%(\mathrm{w} / \mathrm{v})$ concentrations. Emustab ${ }^{\circledR}$ had a lower density at 2, 4, and $6 \%(\mathrm{w} / \mathrm{v})$ concentrations, and displayed low stability at all concentrations. The Neutral-Super-Binder ${ }^{\circledR}$ foaming agent presented greater stability at 8 and $10 \% \quad(\mathrm{w} / \mathrm{v})$ concentrations but did not display suitable density and expansion properties.

The foam density, in the presence of foaming agents Emustab ${ }^{\circledR}$ and albumin, was in the range of 0.29 to $0.56 \mathrm{~g} \mathrm{~cm}^{-3}$. Values less than $0.6 \mathrm{~g} \mathrm{~cm}^{-3}$ are considered satisfactory (Araújo et al., 2017).

With the increase in additive concentration, the foam density of albumin reduced due to the increase in shear rate during the agitation process, which leads to bursting of bubbles. This results in greater incorporation of gas into the mixture and a decrease in foam density. A similar decrease in density has been reported by Thuwapanichayanan et al. (2012) when analyzing the specific mass of banana foam (values of $0.6,0.3$, and 0.27 $\mathrm{g} \mathrm{cm}^{-3}$ for 2,5 , and $10 \%$ concentrations, respectively).

Analysis of the obtained values show that $8 \%$ albumin resulted in greater expansion, compared to other concentrations and other foaming agents. According to Coelho et al. (2019), this is because this parameter is closely linked to density and indicates greater air incorporation and retention that provides greater expansion and reduces density.

All foaming agents showed the opposite trend in all evaluated parameters at a $10 \%$ concentration. According to Bag et al. (2011), this can occur when using high concentrations of certain additives, making the pulp more viscous and preventing air retention. From these results, $8 \%$ albumin was identified as the best foaming agent for the formulation of cagaita pulp foams that were then dried at different temperatures.

The monitoring of sample water losses is depicted in Figure 1, which indicates trends in drying times required to attain a moisture equilibrated state. 


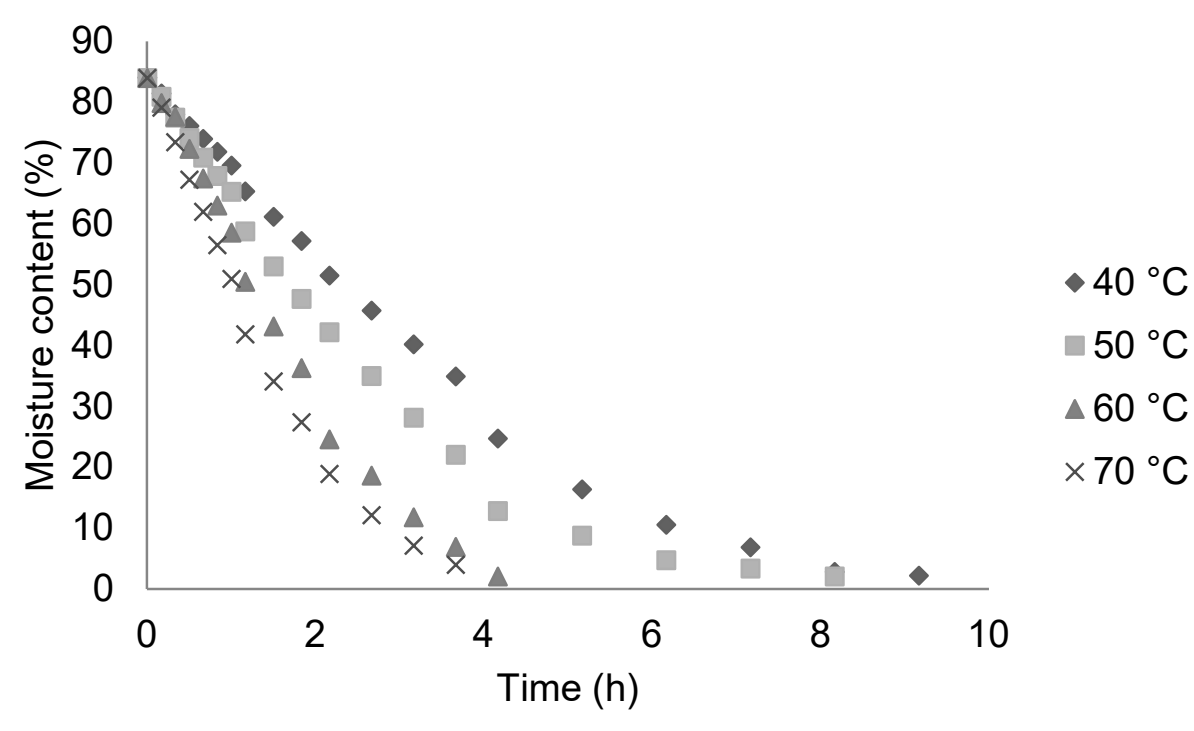

FIGURE 1. Trend lines for the moisture content versus drying time of cagaita pulp at albumin $8 \%$. Albumin pulp had an initial moisture content of $84.05 \pm 1.15 \%$ (w.b). After drying at 40, 50, 60 and $70{ }^{\circ} \mathrm{C}$, the products reached, respectively, moisture content $14.04 \pm 0.74 \%, 12.79 \pm 0.58 \%, 9.47 \pm 0.80$ and $7.75 \pm 0.38 \%$.

As observed in Figure 1, the equilibrium water content reached near constant values the fastest (approximately $4 \mathrm{~h}$ of drying) in the 60 and $70{ }^{\circ} \mathrm{C}$ treatments, whereas the time required was closer to $8 \mathrm{~h}$ for treatments at 40 and $50{ }^{\circ} \mathrm{C}$. The circulating air at higher temperatures has lower humidity, facilitating the absorption of water from the food being processed, reducing drying time, and resulting in products with a lower water content. Such behavior has been previously reported by Araújo et al. (2017) while studying acerola drying in a foam layer.

At all drying temperatures employed, the final product was observed to reach a water content lower than
$25 \%$, which is recommended by the National Health Surveillance Agency (Brasil, 2005). Cagaita dust that was obtained after the drying process could be stored longer, since the reduced water content prevented the proliferation of microorganisms.

In addition, it was necessary to evaluate the physicochemical characteristics and bioactive content of the formed product at different drying temperatures, as since most of these compounds are known to be susceptible to degradation at elevated temperatures. Table 3 presents the physicochemical data, bioactive compounds, and antioxidant capacity of the dried products at different temperatures.

TABLE 3. Results of physicochemical evaluations, vitamin C, vitamin A, carotenoids and antioxidant activity of dry cagaita powder at different temperatures.

\begin{tabular}{ccccccc}
\hline T & pH & ATT & Vit C & AAT (\%) & CT & Vit A \\
\hline 40 & $4.88 \pm 0.01 \mathrm{a}$ & $1.86 \pm 0.04 \mathrm{~b}$ & $114.49 \pm 1.13 \mathrm{c}$ & $56.38 \pm 1.03^{\mathrm{a}}$ & $11.20 \pm 0.22 \mathrm{~b}$ & $93.36 \pm 5.40 \mathrm{~b}$ \\
50 & $4.93 \pm 0.03 \mathrm{a}$ & $1.97 \pm 0.004 \mathrm{~b}$ & $166.14 \pm 3.15 \mathrm{a}$ & $57.06 \pm 0.19^{\mathrm{a}}$ & $8.58 \pm 1.80 \mathrm{c}$ & $71.52 \pm 0.68 \mathrm{c}$ \\
60 & $4.77 \pm 0.03 \mathrm{a}$ & $2.12 \pm 0.002 \mathrm{~b}$ & $129.24 \pm 0.94 \mathrm{~b}$ & $60.44 \pm 1.39^{\mathrm{a}}$ & $11.26 \pm 0.07 \mathrm{~b}$ & $93.82 \pm 6.82 \mathrm{~b}$ \\
70 & $4.05 \pm 0.01 \mathrm{~b}$ & $3.60 \pm 0.01 \mathrm{a}$ & $50.21 \pm 1.90 \mathrm{~d}$ & $31.46 \pm 1.03 \mathrm{~b}$ & $19.77 \pm 0.15 \mathrm{a}$ & $164.80 \pm 0.33 \mathrm{a}$ \\
$\mathrm{CV}$ & 0.60 & 0.90 & 2.27 & 4.02 & 5.49 & 5.49 \\
\hline
\end{tabular}

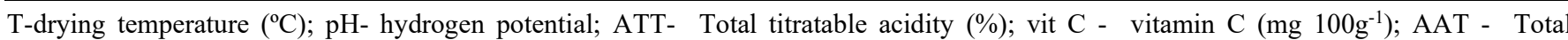
antioxidant activity (\%); CT - Total carotenoids $\left(\mu \mathrm{g} \mathrm{g} \mathrm{g}^{-1}\right)$ and vit A - vitamin A ( $\mu \mathrm{g}$ RAE $\left.100 \mathrm{~g}^{-1}\right)$; CV - Coefficient of variation (\%). Means \pm DS followed by the same lower case letters in the same column do not differ from each other by the LSD test $(p<0.05)$.

The $\mathrm{pH}$ and acidity values remained the same at 40 , 50 , and $60^{\circ} \mathrm{C}$, but was different for the product dried at 70 ${ }^{\circ} \mathrm{C}$. These physicochemical attributes could be associated with the sensory quality of the product as well as protection against proliferation of microorganisms. Although there is no optimal $\mathrm{pH}$ range for foam dried products, there is a normative instruction from the Ministry of Agriculture, Livestock and Food Supply (Brasil, 2018) for pulps and juices, with $\mathrm{pH}$ values ranging approximately from 1.0 to 6.0 . At all drying temperatures, the cagaita pulp foam had a $\mathrm{pH}$ below 5 .
Vitamin $\mathrm{C}$ content was higher at drying temperatures of 50 and $60{ }^{\circ} \mathrm{C}$, with values of 166 and 129 $\mathrm{mg} 100 \mathrm{~g}^{-1}$, respectively. The lowest concentration was 50 $\mathrm{mg} / 100 \mathrm{~g}$, observed in the product dried at $70{ }^{\circ} \mathrm{C}$. This reduction was most likely caused by the thermal degradation of ascorbic acid. According to Resolution No 54 dated November 12, 2012 of the National Health Surveillance Agency, a food that is considered a source of vitamin $\mathrm{C}$ must have at least $15 \%$ of the recommended daily intake (IDR) in a portion of $100 \mathrm{~g}$, and for adults, the IDR for vitamin C is $60 \mathrm{mg}$ (Brasil, 2012). 
In all samples, regardless of drying, the product maintained enough vitamin $\mathrm{C}$ levels to conform to the above guidelines, as established by the legislation. Moreover, these samples showed higher values of vitamin C than those reported by Morais et al. (2017) in araticum pulp (5.27 and $5.75 \mathrm{mg} 100 \mathrm{~g}^{-1}$ in fresh and pasteurized pulp, respectively), and Moreira-Araújo et al. (2019) in murici pulp (58 mg 100g-1) and carnauba (78.1 mg 100 $\left.\mathrm{g}^{-1}\right)$.

Antioxidant activities were highest in samples dried between temperatures of 40 and $60{ }^{\circ} \mathrm{C}$, and had a direct relationship with vitamin $\mathrm{C}$ levels. This was expected, since vitamin $\mathrm{C}$ is a major antioxidant present in several fruits (Morais et al., 2017; Araújo et al., 2017; MoreiraAraújo et al., 2019). These results, except for samples dried at $70{ }^{\circ} \mathrm{C}$, are in overall agreement to those reported in natura cagaita extracts by Rocha et al. (2013). This shows that the foam created in the drying process at temperatures up to $60{ }^{\circ} \mathrm{C}$ maintain a high amount of vitamin $\mathrm{C}$ and high antioxidant activity.

The total carotenoid content in $\beta$-carotene as well as vitamin $\mathrm{A}$ was higher in the sample dried at $70{ }^{\circ} \mathrm{C}$. Tang (2010) has also verified that increased vitamin A bioaccessibility is associated with increasing temperature, signifying that higher temperatures and associated lipid reactions may increase the concentration of these compounds.

The chemical structure of $\beta$-carotene is capable of facilitating its interaction with several types of compounds, including proteins, lipids, and reactive oxygen species (Mesquita et al., 2017). This might justify the higher levels of $\beta$-carotene found in cagaita powder dried at different temperatures, as compared to reports on fresh cagaita pulp by Rocha et al. (2013). The addition of albumin during the preparation of foam leads to the interaction of the former with $\beta$-carotene, maintaining a more stable agglomerate and preventing its loss during the heating process.

\section{CONCLUSIONS}

The $8 \%$ proportion of albumin in cagaita pulp was found to promote optimal density, expansion, and stability of the foam generated during the processing. The physicochemical analysis indicate that the process of drying cagaita pulp with albumin at $40,50,60$, and $70{ }^{\circ} \mathrm{C}$ yields a product that could be stored with a reduced risk of microbial proliferation. The vitamin $\mathrm{C}$ content remained within the established limits at all drying temperatures employed. However, drying at $50{ }^{\circ} \mathrm{C}$ led to a product that would fulfill $200 \%$ of the IDR. Higher concentrations of $\beta$ carotene and vitamin A were also associated with higher drying temperatures. Based on analysis of desirable properties in the final product, such as bioactive compound content, and the production time, temperatures of 60 and $70{ }^{\circ} \mathrm{C}$ was determined to be optimal for producing cagaita powder.

\section{ACKNOWLEDGMENTS}

The authots would like to acknowledge support from the Fundação de Amparo à Pesquisa do Estado de Goiás (FAPEG), the Instituto Federal Goiano, the Coordenação de Aperfeiçoamento de Pessoal do Ensino Superior (CAPES) and the Bheatriz Silva Morais de Freitas.

\section{REFERENCES}

Araújo CS, Macedo LL, Vimercati WC, Saraiva SH, Oliveira NA, Teixeira LJQ (2017) Cinética de secagem de acerola em leito de espuma e ajuste de modelos matemáticos. Brazilian Journal of Food Technology 20: e2016152. DOI: http://dx.doi.org/10.1590/19816723.15216

Bag SK, Srivastav PP, Mishra HN (2011) Optimization of process parameters for foaming of bael (Aegle marmelos L.) fruit pulp. Food and Bioprocess Technology 4(8): 1450-1458. DOI: http://dx.doi.org/10.1007/s1 1947-0090243-6

Brasil (2005) Agência Nacional de Vigilância Sanitária ANVISA. Resolução da Diretoria Colegiada - RDC n ${ }^{\circ}$ 272, de 22 de setembro de 2005. Brasília. Available: http://bvsms.saude.gov.br/bvs/saudelegis/anvisa/2005/rdc0 272_22_09_2005.html. Accessed: Dec 12, 2019.

Brasil (2012) Agência Nacional de Vigilância Sanitária ANVISA. Resolução da Diretoria Colegiada - RDC n ${ }^{\circ}$ 54, de 12 de novembro de 2012. Brasília. Available: http://portal.anvisa.gov.br/documents/\%2033880/2568070/ rdc0054_12_11_2012.pdf/c5ac23fd-974e-4f2c-9fbc48f7e0a31864/. Accessed: Dec 12, 2019.

Brasil (2018) Ministério da Agricultura Pecuária e Abastecimento - MAPA. Instrução Normativa $n^{\circ} 37$, de $1^{\circ}$ de outubro de 2018. Brasília. Available:

http://www.agricultura.gov.br/assuntos/inspecao/produtosvegetal/legislacao-1/biblioteca-de-normas-vinhos-ebebidas/instrucao-normativa-no-37-de-1o-de-outubro-de2018.pdf/view. Accessed: Dec 12, 2019.

Coelho BES, Torres G, Neto AF, Coelho CL (2019) Estudo da estabilidade da espuma da polpa de acerola para secagem pelo método foam-mat drying. Revista Craibeiras de Agroecologia 4(1):e7685.

http://www.seer.ufal.br/index.php/era/article/view/7685/5499.

IAL - Instituto Adolf Lutz (2008) Normas analíticas do IAL: métodos químicos e físicos para análise de alimentos. IAL, 1020p.

Karim AA, Wai CC (1999) Foam-mat drying of starfruit (Averrhoa carambola L.) puree. Stability and air drying characteristics. Food Chemistry 64(3):337-343. DOI: https://doi.org/10.1016/S0308-8146(98)00119-8

Macedo IYL, Garcia LF, Oliveira Neto JR, Leite KCS, Ferreira VS, Ghedini PC, Gil ES (2017) Electroanalytical tools for antioxidant evaluation of red fruits dry extracts. Food Chemistry 217:326-331. DOI: https://doi.org/10.1016/j.foodchem.2016.08.082

Mazuti Silva SM, Gasca Silva CA, Fonseca-Bazzo YM, Magalhães PO, Silveira D (2015) Eugenia dysenterica Mart. Ex DC. (cagaita): planta brasileira com potencial terapêutico. Infarma Ciências Farmacêuticas 27(1):49-95. DOI: https://doi.org/10.14450/2318-9312 
Mesquita SS, Teixeira CMLL, Servulo EFC (2017)

Carotenoides: Propriedades, Aplicações e Mercado. Revista Virtual de Química 9(2):672-688. DOI: https://doi.org/10.21577/1984-6835.20170040

Morais EC, Patias SGO, Ferreira NSS (2017) Compostos bioativos características físico-químicas de polpa de araticum in natura e pasteurizada. Brazilian Journal of Food Technology 20:e2016142. DOI: http://dx.doi.org/10.1590/1981-6723.14216

Moreira TB, Rocha EMFF, Afonso MRA, Costa JMC (2013) Comportamento das isotermas de adsorção do pó da polpa de manga liofilizada. Revista Brasileira de Engenharia Agrícola e Ambiental 17(10):1093-1098. DOI: http://dx.doi.org/10.1590/S1415-43662013001000011

Moreira-Araújo RSR, Barros NVA, Porto RGCL, Brandão ACAS, Lima A, Fett R (2019) Bioactive compounds and antioxidant activity three fruit species from the Brazilian Cerrado. Revista Brasileira de Fruticultura 41(3):e-011. DOI: http://dx.doi.org/10.1590/0100-29452019011

Palmero P, Panozzo A, Simatupang D, Hendrickx M, Loey AV (2014) Lycopene and $\beta$-carotene transfer to oil and micellar phases during in vitro digestion of tomato and red carrot based-fractions. Food Research International 64:831-838. DOI:

http://dx.doi.org10.1016/j.foodres.2014.08.022
Rocha MS, Figueiredo RW, Araújo MAM, MoreiraAraújo RSR (2013) Caracterização físico-química e atividade antioxidante (in vitro) de frutos do Cerrado piauiense. Revista Brasileira de Fruticultura 35(4):933941. DOI: http://dx.doi.org/10.1590/S010029452013000400003

Rufino MSM, Alves RE, Brito ES, Filho JM, Moreira AVB (2006) Metodologia científica: determinação da atividade antioxidante total em frutas no sistema betacaroteno/ácido linoleico. Fortaleza, Embrapa Agroindústria Tropical, p 1-6. Comunicado Técnico 126.

Souza CO, Menezes JDS, Ramos Neto DC, Assis JGA, Silva SR, Druzian JI (2012) Carotenoides totais e Vitamina A de curcubitáceas do Banco Ativo de Germoplasma da Embrapa Semiárido. Ciência Rural 42(5): 926-933. DOI: http://dx.doi.org/10.1590/S010384782012005000024

Tang G (2010) Bioconversion of dietary provitamin A carotenoids to vitamin A in humans. The American journal of clinical nutrition 91(5):1468S-1473S. DOI: http://dx.doi.org/10.3945/ajen.2010.28674G

Thuwapanichayanan R, Prachayawarakorn S, Soponronnarit S (2012) Effects of foaming agents and foam density on drying characteristics and textural property of banana foams. Food Science and Technology 47:348-357. DOI:

http://dx.doi.org/10.1016/j.lwt.2012.01.030 